\title{
Demokrat Parti Döneminde Milli Eğitim Şûraları
}

\section{Hilal AKGÜL}

\begin{tabular}{ccc}
\hline Geliş Tarihi/ Received & Kabul Tarihi/ Accepted & Yayın Tarihi/ Published \\
13/02/2020 & 03/04/2020 & 15/04/2020 \\
\hline Citation/Atıf: Akgül, L., H., (2020), Demokrat Parti Döneminde Milli Eğitim Şuralarl, Atatürk \\
Üniversitesi İktisadi ve İdari Bilimler Dergisi,34(2):631-647, DOI: $10.16951 /$ atauniiibd.688428 \\
\hline
\end{tabular}

Öz: Bu çalışmada DP iktidarı döneminde toplanan Milli Eğitim Şûraları incelenmiştir. Bunların ilki 4 - 14 Şubat 1953 tarihleri arasında çalışan Beşinci Milli Eğitim Şûrası, ikincisi 18 23 Mart 1957 tarihleri arasında çalıșan Altıncı Milli Eğitim Şûrası'dır. Çalışmada önce, DP iktidarı dönemine kadar olan süreçte toplanan milli eğitim şûraları ve milli eğitim şûraları öncesinde toplanmış benzeri toplantılar kısaca anlatılmıştır. Birinci Maarif Kongresi, birinci, ikinci ve üçüncü heyet-i ilmiye toplantıları ile ilk dört milli eğitim şûrası söz konusu toplantılar arasındadır. Ardından temel evreler altında genel hatlarıyla DP iktidarı döneminin siyasal özellikleri gösterilmiştir. Sonrasındaysa DP iktidarı döneminde toplanan iki milli eğitim şûrası ele alınmış, bu şûraların gündemleri, uygulama alanı bulan veya bulamayan önemli kararları sunulmuştur. Çalışmada şûralarda yaşanan önemli tartışmalara da kısaca yer verilmiştir. Son olarak da DP iktidarı döneminde toplanan şûraların genel özelliklerine dair bulgular dikkate alınarak bu şûralar, kendinden önceki şûralar ve benzeri diğer toplantılarla karşılaştırılmıştır. Bu karşılaştırma kapsamında, DP iktidarı döneminde toplanan şûraların kendinden önceki şûralar ve benzeri diğer toplantılardan farklı olan noktaları gösterilmiş ve bu farklılıklar dönemin siyasal özellikleri dikkate alınarak yorumlanmıştır.

Anahtar Kelimeler: Türkiye'de eğitim, Demokrat Parti, Beşinci Milli Eğitim Şûrası, Altıncı Milli Eğitim Şûrası

\section{Natıonal Educatıon Councils Durıng Democrat Party Period}

Abstract: In this study, national education councils which had met during Democrat Party (DP) period, have been viewed. First of these is Fifth National Education Council which had been worked between 4-14 February 1953, second is Sixth National Education Council which had been worked 18-23 March 1957. In study, firstly, national education councils which had met before DP period and similar meetings before national education councils have been briefly explained. First Educational System Congress, first, second and third meetings of Science Committee and first 4 national education councils are subject to these meetings. Then, under basic phases, the political characteristics of DP period have been generally showed. After that, two national education councils which had met in DP period, have been handled, the agendas of these councils and their important decisions which can find or cannot find practical area, have been presented. In study, also important discussions which occured in the councils have been briefly explained. Finally, paying attention to findings about general characteristics of the councils which had met in DP period, these councils have compared to previous councils and similar meetings. Within this

${ }^{1}$ Doç. Dr., İstanbul Bilgi Üniversitesi, Genel Eğitim Fakültesi, Genel Eğitim Bölümü, https://orcid.org/0000-0002-5916-1015 
comparison, the different particulars between councils which had met in DP period and previous meetings have been showed, and paying attention to political characteristic of the period, have been interpreted.

Keywords: Education in Turkey, Democrat Party, $5^{\text {th }}$ National Education Council, $6^{\text {th }}$ National Education Council,

\section{EXTENDED SUMMARY}

Background: In this study, national education councils which had met during Democrat Party (DP) period, have been viewed. First of these is Fifth National Education Council which had been worked between 4-14 February 1953, second is Sixth National Education Council which had been worked 18-23 March 1957. In study, firstly, national education councils which had met before DP period and similar meetings before national education councils have been briefly explained. First Educational System Congress, first, second and third meetings of Science Committee and first 4 national education councils are subject to these meetings. Then, under basic phases, the political characteristics of DP period have been generally showed. After that, two national education councils which had met in DP period, have been handled, the agendas of these councils and their important decisions which can find or cannot find practical area, have been presented. In study, also important discussions which occured in the councils have been briefly explained. Finally, paying attention to findings about general characteristics of the councils which had met in DP period, these councils have compared to previous councils and similar meetings. Within this comparison, the different particulars between councils which had met in DP period and previous meetings have been showed, and paying attention to political characteristic of the period, have been interpreted.

Purpose: The main purpose of this study is to introduce the general characteristics of the national education councils which met in DP period and to compare to previous councils and other similar meetings. Within this comparison, the different particulars between councils which had met in DP period and previous meetings have been showed, and paying attention to political characteristic of the period, aimed to be interpreted.

Literature Review: In study, original meeting minutes and related reports which constitutes the main subject of the study about fifth and sixth national education councils are used. First 4 national education councils which are related to main subject of the study, have been handled by using original meeting minutes and related reports also. In study, beside these sources, main sources wich are related to DP, DP period and education in Turkes have been used, the statistical data has been compiled by official data of Statistical Institution of Turkey. method used.

Methodology: In study, social sciences comparative evaluation research

Results and Conclusions: Fifth National Education Council which was the first national education council of DP period is mainly about primary school 
education. The council put also on the agenda the points about the pre-school education, the kindergartens and the education of the children who need special education. DP gave point to two basic subjects in the Sixth National Education Council which was the second national education council of the DP period. Fist of these is the vocational and technical education, and the second is the public education. In Fifth National Education Council, within religious education at schools fervently discussed but in Sixth National Education Council there was no serious discusson which occupies the general assembly. Two national education councils which had met in DP period, within the requests on organization of the education, represent a continuity with previous national education councils and other similar meetings, it does not represent a break. As in previous meetings, in two councils which had met in DP period, the things which the political power expected from citizens and labor forece requirements of the business/capital circles, creates the basic requests which give shape to the educational system, and within these requests, the educational system is tried to be shaped. But in two councils which had met in DP period, an expansion about the source of the requests which directed to educational system, is determined. From this perspective, Fifth National Education Council has the main importance. In Fifth National Education Council, DP, the requests of the people, their own request, put on the agenda and especially emphasized it. This request is more religious education related. To be put on the agenda this request as a request of people, is related to changing political atmosphere. In competitive political atmosphere, taking into account and providing of this request, will mean taking into account and providing the needs of the voters, and this will be decisive in preference of the voters for political parties.

\section{Giriş}

Bu çalışmada DP (Demokrat Parti) döneminde toplanan Milli Eğitim Şûraları incelenecektir. 14 Mayıs 1950 seçimleriyle iktidara gelen ve Türk Silahlı Kuvvetlerinin yönetime el koyduğu 27 Mayıs 1960 tarihine kadar iktidarda kalan DP döneminde, iki milli eğitim şûrası toplanmıştır. Bunların ilki 4 - 14 Şubat 1953 tarihleri arasında çalışan Beşinci Milli Eğitim Şûrası, ikincisi de 18 - 23 Mart 1957 tarihleri arasında çalışan Altıncı Milli Eğitim Şûrası'dır*.

Çalışmada önce, DP iktidarı dönemine kadar olan süreçte toplanan milli eğitim şûraları kısaca özetlenecek, bu özet milli eğitim şûraları öncesinde yapılan benzer toplantıların mirası da dikkate alınarak genişletilecektir. Maarif Kongresi, birinci, ikinci ve üçüncü heyet-i ilmiye toplantıları ile ilk dört milli eğitim şûrası söz konusu toplantılar arasındadır. Bunun ardından da DP döneminde toplanan söz konusu iki şûra ele alınacak, bu şûraların gündemleri, uygulama alanı bulan veya bulamayan önemli kararları açıklanacaktır. Ayrıca şûralarda yaşanan önemli tartışmalara da genel hatlarıyla yer verilecektir.

* Altıncı Maarif Şûrası adıyla toplanmıştır. 
Çalışmanın temel amacı, DP döneminde toplanan şûraların genel özelliklerini ortaya koyarak, bu şûraları kendinden önceki şûralar ve benzeri diğer toplantılarla karşılaştırmaktır. Çalışmada bu karşılaştırma kapsamında, DP döneminde toplanan şûraların kendinden önceki şûralar ve benzeri diğer toplantılardan farklı olan noktaları gösterilecek ve bu farklılıklar dönemin siyasal özellikleri dikkate alınarak yorumlanacaktır.

\section{Milli Eğitim Şûraları Öncesi Dönem}

Kurtuluş Savaşı'nın sona ermesini izleyen dönemde, Anadolu coğrafyasında, "Türkiye Cumhuriyeti" adını alacak olan çağdaş bir devletin yapılandırılması işine girişildi. $\mathrm{Bu}$ anlamdaki temel adımlar, saltanata son verilmesi, yeni devletin rejiminin cumhuriyet olduğunun ilanı ve hilafetin kaldırılmasıydı. Bu adımlarla siyasal yapı bütünüyle değişiyor ve onun yerini yeni bir yapı alıyordu. Bu adımlar, başka alanlardaki atılımlarla da desteklendi. $\mathrm{Bu}$ atılımların temel amacı, bu adımları güçlendirerek çağdaş Türkiye Cumhuriyeti'nin geleceğini garanti altına almaktı. Eğitim, bu noktada, çok büyük bir anlam kazandı ve eğitim alanını ilgilendiren düzenlemelerle çağdaş Türkiye Cumhuriyeti'nin temel ilkelerini benimseyen ve onlara sahip çıkan yurttaşların yetiştirilmesi önemli bir hedef oldu. $\mathrm{Bu}$ yurttaşlar, çağdaş Türkiye Cumhuriyeti'nin geleceğinin en önemli garantisi olacaktı.

Yeni Türkiye'nin eğitime yükleyeceği öncü rolün ilk işaretleri aslında Kurtuluş Savaşı döneminde verilmişti. Örneğin bu yazının konusunu teşkil eden Milli Eğitim şûralarının da başlangıcı olarak kabul edilen ve Türkiye eğitim tarihinde önemli bir yeri bulunan Birinci Maarif Kongresi, Kurtuluş Savaşı sürerken, bu savaşın oldukça kritik bir evresine denk gelen Sakarya Savaşı'nın hemen öncesinde, 16 Temmuz 1921 tarihinde Ankara'da toplanmıştı. Çalışmalarını 21 Temmuz 1921 tarihine kadar sürdüren ve 250'den fazla öğretmenin katıldığı kongrenin açılışı, bizzat TBMM Başkanı Mustafa Kemal tarafindan yapılmıştı. Kongreden beklenen, genç kuşakları çağın gereklerine göre yetiştirip onlara rehberlik edecek bir eğitim sistemini ortaya koymaktı. Mustafa Kemal bunu kongrenin açış konuşmasında “... kongrenizden ... yeni bir sanat ve marifet yolu bulup millete göstermek ve o yolda yeni nesli yürütmek için rehber olmak gibi mukaddes bir hizmet bekliyoruz" diyerek dile getirmişti (Atatürk'ün Söylev ve Demeçleri, 1997: 20). Kongrede temelde halk mektepleri projesi, ilköğretimin süresi, ders programlarına çalışma yaşamına dönük dersler konulması konuları tartışıldı. Ancak Kurtuluş Savaşı'nın devam ediyor olması Birinci Maarif Kongresi'nin çalışmalarının sonuca ulaştırılabilmesini engelledi (Sakaoğlu, 2003: 160 - 162; Akyüz, 1985: 302 - 303).

Kurtuluş Savaşı'nın 11 Ekim 1922 tarihli Mudanya Mütarekesi'yle sona ermesinin ardındansa, TBMM Başkanı Mustafa Kemal, Bursa'da öğretmenlere hitaben, dikkat çekici bir konuşma yaptı. Mustafa Kemal, 27 Ekim 1922 tarihli bu konuşmasında, “... Ordularımızın ihraz ettiği zafer, sizin ve sizin ordularınızın zaferi için yalnız zemin hazırladı... Hakiki zaferi siz ihraz ve idame 
edeceksiniz" ifadelerine yer vermekte ve eğitim alanını yeni Türkiye'nin esas mücadele alanı olarak göstermekteydi (Atatürk'ün Söylev ve Demeçleri, 1997: 49).

Türkiye Cumhuriyeti'nin, eğitim alanındaki ilk köklü düzenlemesiyse 3 Mart 1924 tarihli Öğretimin Birleştirilmesi Yasası'yla (Tevhidi Tedrisat Kanunu) yaşama geçirildi. $\mathrm{Bu}$ yasayla, çeşitli bakanlıklara bağlı olarak faaliyetlerini sürdüren tüm okullar Milli Eğitim Bakanlığı'na bağlandı. Öğretimin Birleştirilmesi Yasası'yla okulların tek çatı altında toplanmasını eğitim programlarının ve öğretmen yetiştirme sisteminin yeni gereklere göre düzenlenmesi izledi. Ardından da eğitimin yaygınlaştırılmasına yönelik çalışmalara hız verildi.

Eğitim alanındaki bu gelişmeler, bütünüyle olmasa bile, büyük ölçüde heyet-i ilmiye toplantılarında alınan kararlara paralel olarak yaşanmaktaydı. 1923 - 1925 yılları arasını kapsayan bu dönemde, üç heyet-i ilmiye toplantısı yapıldı. Toplantıların ilki Birinci Heyet-i İlmiye adıyla 15 Temmuz - 15 Ağustos 1923 tarihleri arasında düzenlendi. Eğitim programlarının yeniden hazırlanması, önemli görülen bazı yabancı eserlerin Türkçeye çevrilmesi, bir ulusal sözlügün ve dil bilgisi kitabının yazılması, bir ulusal arşivle ulusal tarih kütüphanesinin oluşturulması Birinci Heyet-i İlmiye'nin temel kararlarıydı. Ayrıca tarih ve coğrafya enstitülerinin kurulması, İlköğretim Kararnamesi'nin değiştirilmesi, öğretmen okullarının tüzük ve programlarının yenilenmesi ve bu okullara birer orta bölüm eklenmesi de benimsenen kararlar arasında bulunuyordu. $\mathrm{Bu}$ kararların çok büyük bir bölümü, toplantının sona ermesinin hemen ardından uygulamaya kondu (Sakaoğlu, 2003: 162 - 163; Zelyut, 1996: 676; Yücel, 1994: $21-22)$.

İkinci Heyet-i İlmiye, Eğitimin Birleştirilmesi Yasası'nın çıkartılmasının hemen sonrasında, 23 Nisan 1924 - 1 Mayıs 1924 tarihleri arasında çalıştı. İlkokulların eğitim süresinin beş yıl olarak belirlenmesi ve programlarının yeniden hazırlanması, ortaokul ve liselerin eğitim sürelerinin üçer yıllık iki aşamadan oluşacak biçimde düzenlenmesi ve böylece toplam 7 yıldan 6 yıla düşürülmesi İkinci Heyet-i İlmiye'nin üzerinde fikir birliğine vardığı temel konulardandı. Bunların yanı sıra, dört yıllık öğretmen okullarının programlarının yeni gereklere göre değiştirilmesiyle kimi ders kitaplarının yeniden yazılması da bu toplantıda karara bağlandı. Bu kararların da yine büyük bir bölümü, 1924 1925 ders yılından başlayarak, aşamalı olarak uygulamaya geçirildi (Sakaoğlu, 2003: 176; Zelyut, 1996: 676; Yücel, 1994: 25 - 26).

Üçüncü Heyet-i İlmiye'yse çalışmalarına 26 Aralık 1925 tarihinde başladı. 8 Ocak 1926 tarihine kadar sürdürülen çalışmalar sonucunda, devlet ve il bütçelerinden eğitime ayrılan payın yükseltilmesi ve okulların kapasitesinin tüm başvuranları alabilecek kadar genişletilmesi yönünde kararlar alındı. Heyet, liselerin düzenlenmesi, belirli merkezlerde büyük ve daha nitelikli eğitim veren liselerin açılması ve bu türden liselerin sayısının artırılması, öğretmen okullarıyla teknik okulların belirli merkezlerde toplanarak geliştirilmesi, yatılı olmayan 
okullarda karma eğitim uygulamasının yaygınlaştırılması gibi konuları da karara bağladı. Bu kararlar da, aynı Birinci Heyet-i İlmiye ve İkinci Heyet-i İlmiye kararlarında olduğu gibi, izleyen dönemde çok büyük ölçüde uygulama alanı buldu (Sakaoğlu, 2003: 177 - 178; Zelyut, 1996: 676; Yücel, 1994: 27).

\section{Dp Öncesi Dönemin Milli Eğitim Şûraları}

Üçüncü Heyet-i İlmiye'nin çalışmaları sona erdikten sonra, Türkiye'de bu türden bilimsel toplantılar 14 yıl boyunca yapılmadı. Milli Eğitim Bakanı Hasan Âli Yücel başkanlığında 17 - 29 Temmuz 1939 tarihleri arasında toplanan Birinci Milli Eğitim Şûrası*, uzunca bir aradan sonra yapılan, bu türden ilk toplantı olması bakımından önem taşıyordu. Eğitimin plan ve ilkeleri, çeşitli derecelerdeki okullara ilişkin yönetmelikler ve eğitim programları gündemin temel maddeleri oldu (Birinci Maarif Şûrası, 1939: I - II, Dinç, 2015: 21 - 43).

İkinci Dünya Savaşı döneminde toplanan İkinci Milli Eğitim Şûrası** çalışmalarına 15 Şubat 1943 tarihinde, yine Milli Eğitim Bakanı Hasan Âli Yücel'in başkanlığında başladı. Şûra'nın üç temel gündem maddesi bulunuyordu: Ahlak eğitiminin geliştirilmesi, ana dil çalışmalarında verimin artırılması ve tarih öğretiminin yöntem ve araçlar bakımından incelenmesi (İkinci Maarif Şûrası, 1943: XIII - XIV; Dinç, 2015: 49 - 65).

Üçüncü Milli Eğitim Şûrası 2 - 10 Aralık 1946 tarihleri arasında, İkinci Dünya Savaşı döneminin hemen sonrasında çalıştı. Milli Eğitim Bakanı Şemsettin Sirer başkanlığında toplanan bu Şûrada, ticaret ve erkek sanat okullarıyla kız enstitülerinin program ve yönetmelikleri, İstanbul Teknik Okulu yönetmeliği, orta dereceli tüm okulların öğretmen ve öğrencilerine ilişkin mevzuatın günün gereklerine göre düzenlenmesi temel gündem maddeleriydi. Okul - aile arasında işbirliği sağlanması için gereken önlemler de temel gündem maddeleri arasında tartışıldı (Üçüncü Milli Eğitim Şûrası, 1947: IX - X; Dinç, 2015: $71-90)$.

Dördüncü Milli Eğitim Şûrası'ysa 22 - 31 Ağustos 1949 tarihleri arasında toplandı. Şûranın başkanlığını Milli Eğitim Bakanı Tahsin Banguoğlu yürüttü. Şûranın gündeminde 1948-49 ders yllından itibaren uygulanmaya başlanan ilkokul programı, yeni ortaokul programı projesi, lise ders konularının tespiti, ortaokullara ve liselere öğretmen yetiştiren eğitim enstitüleri ve yüksek öğretmen okulu teşkilatının ihtiyaçlara göre düzenlenmesi bulunuyordu (Dördüncü Milli Eğitim Şûrası, 1949: IX; Dinç, 2015: 99 - 114). Bu şûranın gündeminde yer alan eğitim ve öğretimde dayanılan demokratik esasların gözden geçirilmesine yönelik gündem maddesiyse oldukça dikkat çekiciydi. Bu konu, heyet-i ilmiye toplantıları ve daha önce yapılan milli eğitim şûralarının gündemine hiç alınmamıştı. Bu konuya şûrada ayrılan yer, bir rastlantıdan çok, o dönem Türkiye'sinin koşullarıyla ilgili gözüküyordu. Çok partili yaşama geçiş sonrası

\footnotetext{
* Birinci Maarif Şûrası adıyla toplanmıştır.
}

** İkinci Maarif Şûrası adıyla toplanmıştır. 
iktidar mücadelesinin kızıştığı bir ortamda toplanan bu şûra, eğitim ve öğretimde dayanılan demokratik ilkelere ilişkin hazırladığ raporla ve bu rapor çerçevesinde alınan kararlarla, yeni siyasal koşulların gereksediği eğitim sisteminin nasıl kurulacağını göstermeye çalışıyordu. Şûranın eğitimde demokratikleşmeyi, toplumsal ve siyasal demokratikleşmenin ön koşullarından biri, hatta birincisi olarak algılaması ve demokratik sisteme katkı sağlaması için eğitim sistemini demokratikleştirmeyi amaçlaması önemliydi. Çağdaş Türkiye Cumhuriyeti'nin yapılandırılması sırasında önemli ve belirleyici bir misyonun öznesi olan eğitim, İkinci Dünya Savaşı sonrası dönemde çok partili siyasal yaşama geçilirken de yine benzer bir misyonla donatıliyordu (Akgül, 2006: 175 - 187)

\section{DP Dönemi’nin Milli Eğitim Şûraları}

Beşinci ve altıncı milli eğitim şûraları, Türkiye'de iktidarın ilk kez el değiş̧tirmiş olduğu bir dönemde, DP iktidarı altında toplandı. Aşağıda önce kısaca DP iktidarı dönemine ana hatlarıyla değinilecek, ardından biri 1953 diğeri 1957 yılında toplanan DP iktidarı döneminin iki milli eğitim şûrası ele alınacaktır.

\subsection{Genel Hatlarıyla DP Iktidarı Dönemi}

DP, 7 Ocak 1946 tarihinde, Celal Bayar, Adnan Menderes, Refik Koraltan ve Fuat Köprülü tarafindan kuruldu. DP'nin kuruluşunun ardından yaşanan en önemli gelişme, 21 Temmuz 1946 tarihinde yapılan genel seçimler oldu. CHP, 1947 yılında yapılması gereken seçimleri yaklaşık bir yıl öne alarak erken genel seçime gitmeyi tercih etti. Seçim öncesi dönemde yaşananlar, DP'ye gittikçe büyüyen bir ilginin ve desteğin varlığına işaret ediyordu. Ancak seçim sonuçları bu ilgi ve desteği yansıtır nitelikte olmadı. 1946 seçimlerinde 465 milletvekilliği için 273 aday gösteren DP, TBMM'ye yalnızca 62 milletvekili yollayabilecek oy topladı. Seçimlerin hemen sonrasında, DP'nin seçim sonuçlarına şiddetli itirazlarıyla karşılaşıldı ancak sonuç değişmedi (Tunaya, 1952: 646 vd.).

1946 seçimleri sonrası, Türkiye'deki siyasal ortama çoğu zaman DP ve CHP arasındaki gerginlikler hâkim oldu. Ancak bu gergin siyasal ortamda, Türkiye yine de göreli daha demokratik bir seçim sistemini kurmayı başardı. TBMM, 16 Şubat 1950 tarihinde, gizli oy, açık ayırma ve yargı denetimini sağlayan yeni bir seçim yasasını benimsedi, Yargıtay ve Danıştay üyelerinden oluşan Yüksek Seçim Kurulu oluşturuldu. Ayrıca yasa, basit çoğunluk ilkesini il bazında geçerli kıldı. Böylece Türkiye, çok partili dönemin ikinci genel seçimi olacak 14 Mayıs 1950 seçimlerine, demokratik seçimler açısından büyük ölçüde hazır hale getirildi (Tekeli, 1983: 1803).

Türkiye, 14 Mayıs 1950 tarihinde bir "dönüm noktası" olarak anılan seçimle "sandık başına" gitti. Seçimde ağırlıklı olarak CHP ve DP çekişti. Seçime katılma oranı yüzde 90 düzeyindeydi (İstatistik Göstergeler: 1923 - 1995, 1996: 92). Seçimin son derece dürüst ve büyük bir olgunluk içinde geçtiği yaygın biçimde kabul gördü. Seçim sonuçları açıklandığında, seçimin "mutlak" galibinin DP olduğu anlaşıldı. DP, geçerli oyların yüzde 53'ünü toplamış ve meclise 408 milletvekili göndermeye hak kazanmıştı. CHP, geçerli oyların yüzde 40'ını aldı. 


\section{Demokrat Parti Döneminde Milli Eğitim Şûralarl}

$\mathrm{Bu}$ sonuca göre, $\mathrm{CHP}$, meclise 69 milletvekili gönderebilecekti. Bu sonuçlara göre, meclisin, yüzde 84'ünü DP, yüzde 14'ünü CHP milletvekilleri oluşturdu; yeni mecliste yüzde 2 oranında da bă̆ımsız milletvekili bulundu (İstatistik Göstergeler: 1923 - 1995, 1996: 92).

14 Mayıs 1950 seçimleri ile başlayan DP iktidarı 1954 ve 1957 genel seçimlerinden de birinci parti olarak çıkarak, iktidarını 27 Mayıs 1960 tarihinde Türk Silahlı Kuvvetleri'nin yönetime el koymasına kadar devam ettirdi. DP iktidarı döneminin ilk genel seçimi 2 Mayıs 1954 tarihinde yapıldı. Seçime katılma oranı yine yüzde 90 düzeyindeydi. DP, bu seçimde, geçerli oyların yüzde 57'sini, CHP yüzde 35ini aldı. CMP (Cumhuriyetçi Millet Partisi) ise oyların yüzde 4,8'ini topladi. Bu sonuçlara göre, TBMM'ye DP 489, CHP 31 ve CMP de 5 milletvekili göndermeye hak kazandı. Ayrıca 12 bağımsız milletvekili de TBMM'ye girdi. Mecliste DP'nin yüzde 91, CHP'nin yüzde 6, CMP'nin yüzde 1 ve bağımsızların da yüzde 2 oranında temsil edildiği anlaşılıyordu (İstatistik Göstergeler: 1923 - 1995, 1996: 92). 1954 genel seçimi sonuçları, DP için tartışmasız bir başarıydı. DP, iktidarın yıpratıcılığını yaşamamış, tersine 1950 genel seçiminde yüzde 53 olan oy oranını yüzde 57'ye yükseltmiş; en yakın rakibi CHP'nin 1950 genel seçiminde yüzde 40 olan oy oranının yüzde 35'e gerilemişti. $\mathrm{Bu}$ durum, TBMM'deki sandalye dağılımına da yansımış, 1950 genel seçim sonuçlarına göre TBMM'nin yüzde 84'ünü oluşturan DP, TBMM'deki sandalyelerinin oranını yüzde 91'e ulaştırmıştı.

DP iktidarı döneminin ikinci ve son genel seçimiyse 27 Ekim 1957 tarihinde yapıldı. Seçime katılma oranı yaklaşık yüzde 77 civarındaydı. DP geçerli oyların yüzde 47'sini, CHP yüzde 41'ini, CMP yüzde 7'sini, HP (Hürriyet Partisi) de yüzde 3,8'ini aldı. Bu sonuçlara göre, TBMM'ye DP 419, CHP 173, CMP 4 ve HP de 4 milletvekili gönderebilecekti. Bu arada, 2 bağımsız milletvekili de TBMM'ye girme hakkı kazanmıştı (İstatistik Göstergeler: 1923 1995, 1996: 92). Seçim sonuçları yine DP'nin başarısına işaret ediyordu. Ancak DP'nin oy oranı, 1954 genel seçimine göre epey gerilemiş, yüzde 57'den yüzde 47'ye düşmüştü. DP'nin en yakın izleyicisi CHP'yse 1954 genel seçiminde yüzde 35 olan oy oranını, bu seçimde yüzde 41'e çıkartarak, iktidar partisine oy oranı açısından ciddi bir biçimde yaklaşmıştı. Bu durum TBMM içindeki dağılıma da yansıdı. 1954 genel seçimi sonrasında TBMM'deki sandalyelerin yüzde 92'sine sahip olan DP, 1957 genel seçimi sonrasında TBMM'deki sandalyelerinin büyük bölümünü yitirdi.

DP iktidarı döneminde, Menderes başkanlığında 5 farklı hükümet kuruldu. Bu hükümetlerden ikisi 1950 - 1954 seçimleri arasında, 22 Mayıs 1950 - 9 Mart 1951 ve 9 Mart 1951 - 17 Mayıs 1954 tarihlerinde görev yaptı. 1954 - 1957 seçimleri arasında kurulan iki hükümetinse görev tarihi 17 Mayıs 1954 - 9 Aralık 1955 ve 9 Aralık 1955 - 25 Kasım 1957 arasını kapsadı. 1957 seçimleri sonrasında kurulan hükümetse $25 \mathrm{Kasım} 1957$ - 27 Mayıs 1960 tarihleri arasında görevde kaldı. DP tarihi yazınında, 1950 - 1954 yılları arasını kapsayan dönem DP’nin “altın yılları" olarak değerlendirilmekte, 1954 - 1957 yılları arası dönem 
belli sorunlar baş göstermiş olsa da yine DP'nin başarılı dönemi olarak anılmakta; 1957 sonrası dönemse DP'nin çöküş dönemi olarak nitelenmektedir (Eroğul, 1998).

\subsection{Beşinci Milli Eğitim Şûrası (4 - 14 Şubat 1953)}

Beşinci Milli Eğitim Şûrası'nın çalışmaları 04 Şubat 1953 tarihinde, Ankara Gazi Eğitim Enstitüsü'nde başladı (Beşinci Milli Eğitim Şûrası, 1954: X - XI). Şûranın çalışmaları 14 Şubat 1953 tarihine kadar, 10 gün süreyle devam etti. Bu şûra, DP iktidarı döneminin ilk milli eğitim şûrasıydı ve DP'nin kurduğu ikinci hükümet döneminde gerçekleştiriliyordu. 326 delegenin katıldığ 1 şûranın başkanı, ikinci DP Hükümeti’nde Milli Eğitim Bakanlığı görevini yürüten Tevfik İleri’ydi (Beşinci Milli Eğitim Şûrası, 1954: XIIV - XVIII).

Milli Eğitim Bakanı İleri, şûranın açış konuşmasında gelecek 20 - 25 yılın Türkiye için önemli bir dönem olacağına ve bu dönemde eğitimin rolüne şu sözlerle dikkat çekti:

"Herkesçe bilinen şu hakikatleri burada bir kere daha tekrar etmeyi faydalı buluyorum: Önümüzdeki yirmi, yirmi beş yll memleketimiz için ehemmiyetli ve pek hayatî bir devredir. Yeni Türk nesillerini ilmi usullerle ve asrın ihtiyacına uygun şekilde yetiştirmek mecburiyetindeyiz." (Beşinci Milli Eğitim Şûrası, 1954: 21)

Sözlerine bu zorunluluğu gerçekleştirmek için beklentileri açıklayarak devam eden İleri, konuşmasında şu ifadelere yer verdi:

"Bu zarureti gerçekleştirmek için herhangi bir tılsımdan medet umacak vaziyette değiliz. Milletimiz, gayeye varabilmemizin teminini milli eğitim teşkilatımızdan beklemektedir. Çocuklarımızı, yaptıklarını bilerek yapan, milli ideale bağll, ruhlart ve şahsiyetleri üstün birer insan olarak yetiştireceğiz. Çocuklarımız, sonsuz bir çalışma ihtirası taşımalı, başarının zevkini duymal, tembel ve tufeyli yaşamaktan nefret etmeli, organizasyon kabiliyetlerini geliştirmeli, iyi ahlakl, yapıcı ve yaratıcı vatandaşlar olmalıdırlar. Talim ve terbiye usullerimizde ne kadar kuvvetlenirsek, bu üstün ideale o derece yaklaşmış olacağız. Çalışmalarınız bizi bu bakımlardan da aydınlatacaktır." (Beşinci Milli Eğitim Şûras1, 1954: 21 - 22)

İleri konuşmasında, şûranın gündeminde olan konulara da değinerek, hem bu konulara ilişkin somut verileri hem de hükümetinin görüşlerini aktard1. İlköğretimin yaygınlaşması, ilköğretim müfredatı ve programları, İlköğretim Kanun Taslağı, İlköğretim Yönetmeliği, öğretmen yetiştirme, okul öncesi eğitim, özel eğitime muhtaç çocuklar İleri'nin konuşmasında değindiği ana başlıklardı (Beşinci Milli Eğitim Şûrası, 1954: 5 - 21).

Şûranın gündeminde bulunan temel konularsa aşağıdaki gibi belirlendi:

1. İlköğretim Kanunu tasarısının incelenmesi ve zorunlu ilköğrenimin planlanmasi; 


\section{Demokrat Parti Döneminde Milli Eğitim Şûraları}

2. İlkokullara öğretmen yetiştirilmesi, öğretmen okullarıyla köy enstitüleri yeni öğretim programı ve meslekte olgunlaşma konularının incelenmesi;

3. İlkokul programının gözden geçirilmesi;

4. Yeni İlkokul Yönetmeliği tasarısının incelenmesi;

5. Okul öncesi eğitim ve anaokulları için hazırlanmış olan program ve yönetmeliğin incelenmesi;

6. Özel eğitime muhtaç çocuklar için hazırlanmış olan raporla yetiştirme yurtlarına ait yönetmeliklerin incelenmesi ve korunmaya muhtaç çocuklar hakkındaki kanunun gözden geçirilerek değişiklik gerektiren kısımlarının araştırılması;

7. İlkokullarda sağlık konusu ile ilgili alınması gereken önlemlerin saptanması. Maddi ve manevi bakımdan çocukları koruyan mevzuatın incelenmesi, gerek görülürse bu mevzuatın iyileştirilmesine veya yeni hazırlanacak Çocukları Koruma Kanunu'na temel teşkil edecek bir raporun hazirlanmas1;

8. İlkokul öğretmenlerini ilgilendiren diğer konular ve genel olarak ilköğretim sorunlarına ilişkin Şûra üyelerinin tekliflerinin incelenmesi. (Beşinci Milli Eğitim Şûras1, 1954: IX)

Şûra, bu gündem maddelerini ayrı ayrı ele alacak 8 farklı komisyona ayrıldı (Beşinci Milli Eğitim Şûrası, 1954: XXIX - XXXIV). Komisyonlar, ilgili oldukları gündem maddesini tartışıp bu tartışmalar ışı̆̆ındaki raporlarını hazırladı. Ardından komisyonlardan gelen raporlar genel kurulda görüşülerek ve gerekli görüldüğü durumlarda değişiklikler yapılarak kabul edildi.

Şûranın bazı kararları Türkiye eğitimi üzerinde etkili olmuş; şûranın bazı kararlarıysa uygulama alanı bulamamıştır. Şûranın gündemi bir bütün olarak değerlendirildiğinde, asıl ağırlı̆̆ın ilkokul eğitimi üzerinde olduğu görülmektedir. Şûranın aldığı en önemli kararlar da ilkokul programıyla ilgili olmuştur. Ancak ilgili komisyonun raporuyla önerilen ve genel kurulda onaylanan bu program, uygulama imkânı bulamamış; yeni ilkokul programının uygulaması için Türkiye 1961 yılına kadar beklemek zorunda kalmıştır. Bu arada belirtmek gerekir ki 1961'de uygulamasına geçilen yeni ilkokul program, Beşinci Milli Eğitim Şûrası'nda hazırlanan programdan izler taşımakla birlikte, şûrada kabul edilen programdan hayli farklıdır (Dinç, 2015: 156).

Şûranın önemli kararlarından biri de yine ilkokul eğitimi kapsamında, ilkokullara öğretmen yetiştirilmesiyle ilgili olmuştur. Şûra bu kapsamda "ilköğretmen okulları" modelini önermiş ve bunun ayrıntılarını ortaya koymuştur. İzleyen dönemde 6234 sayılı ve 27 Ocak 1954 tarihli kanunla İlköğretmen Okulları kurulduğu ve şûranın bu kararının uygulamaya yansıdığı görülmektedir. $\mathrm{Bu}$ arada belirtmek gerekir ki aynı kanunla Köy Enstitüleri kapatılmış ve bu enstitülerin görevleri İlköğretmen Okulları'na devredilmiştir (Dinç, 2015: 157).

Şûranın okul öncesi eğitim ve anaokulları için hazırlanmış olan program ve yönetmeliğin incelenmesiyle görevli komisyonunun raporuysa Türkiye'de 
okul öncesi eğitimle ilgili ilk kapsamlı bilimsel belge olması bakımından önem taşır (Dinç, 2015: 142). Bu raporu, Beşinci Milli Eğitim Şûrası'nın eğitime önemli ve aynı zamanda özgün bir katkısı olarak değerlendirmek mümkündür. Öte yandan, özel eğitime muhtaç çocuklarla ilgili komisyonun raporu da şûranın önemli bir katkısı olarak görülebilir. Şûradan kısa süre sonra 1953 yılı içinde, Gazi Eğitim Enstitüsü'nde, Özel Eğitim Bölümü kurulduğunun da altını çizmek ve bu anlamda uygulamaya geçildiğini de belirtmek gereklidir. Bu bölüm 1955 yılında kapatılmış olsa da özel çocukların eğitimi kapsamında önemli bir deneyimi ve örneği oluşturmuştur (Dinç, 2015: 156).

Şûranın en hararetli tartışmalarınınsa din eğitimi kapsamında, ilkokul programının gözden geçirilmesiyle ilgili komisyonun raporu genel kurulda ele alınırken yaşandı (Dinç, 2015: 142). Tartışmalar daha çok ilgili raporun 15'inci maddesiyle ilgiliydi. Raporun bu maddesi şöyledir:

\section{"Madde 15}

Din dersleri ögretimi ile ilgili olarak

a. Müfredattaki itikadi kısımların çocuk ruhuna ve pedagojik ölçülere uygun şekilde tadili;

b. Islam tarihinden, peygamberimizin ve büyük din adamlarının hayatlarından ancak çocuk için cazip ve ahlaki değer taşıyan hikaye ve menkibelerin alınmasi;

c. Metafizik kisımlardan ahiret, ölüm, kader gibi konuların işlenmesinde, çocuk seviyesini aşan derinliklere gidilmemesi;

d. Bütün din ögretiminde dogmatik olmaktan sakınılarak yumuşak, tatl, sicak telkinler yapılması

muvaffik görüldü.

Ihtiyari olan bu dersler için not takdiri lüzumlu görülmüs fakat bunun sinıf geçmede müessir olmaması ve din ögrretiminin ders saatleri içinde kalması esasları da kabul edilmiştir." (Beşinci Milli Eğitim Şûrası, 1954: 354)

Konuyla ilgili tartışma kapsamında en önemli ve kapsamlı eleştiri Ankara Üniversitesi Hukuk Fakültesi öğretim üyelerinden anayasa hukuku profesörü Bülent Esen tarafından getirilmiştir. Esen eleştirilerini din ve vicdan özgürlügü ile laik devlet yapısı ekseninde sunmuştur. Konuşmasında;

"Rapor, çok ileri bir Türkiye görüşü ile tanzim edilmiştir. Yalnız bunun içinde bir kambur, bir sui teşekkül gördüm. Bendenize öyle geliyor ki komisyon bir emri vakinin kurbanı olmuştur. Meseleleri esasından münakaşa etmeyi düşünmemiştir. Bu bakımdan bir pürüzlü nokta kalmıştır. Bu nokta raporun 15 'inci maddesini teşkil eden meseledir. ... Bendeniz terbiyeciyim. Küçük çocuk terbiyecisi değilim, kâhil insan terbiyecisiyim. Bunun yanı başında hukukçuyum. Türk anayasasının ikinci maddesinde devletin laik olduğu hakkinda bir prensip vardir. Türkiye Evkaf ve Şeriye Vekaletlerinin ilgası hakkında bir kanun vardır. 
Bu kanunun bir 4. maddesi vardır. Hükümet ve Büyük Millet Meclisi devletin içerisinde, devletin organlarl olarak yalnuz halka taalluk eden meselelerle uğraşırlar. İtikadatla uğraşmazlar. Bu Mustafa Kemal zamanında çıkmıştır. O Mustafa Kemal ki 1925 senesinde Samsun'a giderken yolda verdiği nutukta bu memlekette milli terbiyenin esas olacağını ve dini terbiyenin yeri bulunmadığını söylemiştir." (Beşinci Milli Eğitim Şûras1, 1954: 373)

ifadelerine yer veren Esen, açıklamalarını şöyle sürdürmüştür:

"Çok rica ediyorum, 1953 milat yılında yaşıyoruz. 1948 senesinde çıkmış Insan Haklarl Evrensel Beyannamesi'ne biz de imzamizl attı. Bu vesikanın 18. Maddesi diyor ki herkes inanışında ve dini akidesinde serbesttir. Ancak özel surette eğitimle bunu sağlamak mümkündür. Resmi eğitimle bunu sağlamamalıyız. Meselenin esasını niçin münakaşa etmediniz? Rica ederim Türkiye teokratik bir devlet değildir. Gerçi getirdiğiniz çareler Pakistan devletinin anayasasına göre çok yerindedir. Fakat Pakistan teokratik bir devlettir. Türkiye teokratik değildir." (Beşinci Milli Eğitim Şûrası, 1954: 373 - 374)

Esen sözlerini şöyle noktalamıştır:

"Hür vatandaş yetiştirmek istiyorsak akidelerinde hür birakmak mecburiyetindeyiz. Rica ederim vazifelerimizi rasaneti zihniye ile tetkik edelim. Ben bir hukuk adamıyım, kanunlara bağll bir kimse olarak, Anayasa'ya bağll bir kimse olarak diyorum ki bu dersin programlardan çıkarılması hususunda bir temenni izhar etmemiz lazımdl. İşte ben bu temenniyi izhar etmek için huzurunuza çıktım." (Beşinci Milli Eğitim Şûras1, 1954: 374)

Genel Kurul'da Esen'i destekleyen başka delegeler de söz almış, bazı delegeler de Esen'in sunduğu görüşlere karşı görüşler içeren konuşmalar yapmış ve ilgili maddeyi savunmuştur. İlgili maddeyi savunup, Esen'in sunduğu görüşlere karşı en önemli konuşmaysa Milli Eğitim Bakanı Tevfik İleri tarafından yapılmıştır. İleri konuşmasında,

"Anayasamız vicdan hürriyetine hürmet eder. Medeni Kanunumuz bütün vatandaşların çocuklarına din telkinatında bulunmasını kabul eder. İşte bir hükümet olarak vatandaşların arzusunu bir noktada toplayarak tahakkuk ettirmeye çalıştı. Milletin arzusuna rağmen hükmetmek niyetinde değiliz. Çocuklarına din dersi verdirmek istemeyen vatandaşlara hudutsuz serbesti verdik. Hiç karlşmıyoruz, ne devam mecburiyeti, ne okuma ve ne de not alma mecburiyeti vardir. Vicdan hürriyetine bundan fazla hürmet olur mu?" (Beşinci Milli Eğitim Şûras1, 1954: 380 - 381)

ifadelerini kullanarak şöyle devam etmiştir:

"Vatandaş çocuğuna din dersi okutmak istiyor. Yani Müslümanlık terbiyesi verdirmek, bunun iptidai bilgilerini ögretmek istiyor. İki şık var, Medeni 
Kanun ona bu hakk tanıdığına göre ya diyeceksiniz ki ben mekteplerime bunu sokmam, istediğin yerde istediğine din dersi verdir. O takdirde korkunç hadise vukua gelir. Mücadele etmeye mecbur olduğumuz mahalle mektebi, mollanin mektebi postu serer. Amma sen ona okutmayacaksın, o cahildir, okutmayacaksın, ben de okutmayacağım ama sen Kanunu Medeni, Teşkilatı Esasiye Kanunu mucibince vicdan hürriyetine maliksin, dini terbiye ve bilgi vermek hakkına maliksin. Bu ne demektir, bu yamaçtan o yamaca geçmeye maliksin ama arada köprü yoktur, köprü olmayınca tabii geçilmez. Köprüyü geçmek hakkına sahip oldun mu, köprüyü kurmak bir borçtur. Biz bunu yaptık. Köprüyü kurduk." (Beşinci Milli Eğitim Şûras1, 1954: 381)

İleri bunun yapılmasıyla gericilikle mücadele kapsamında önemli bir kazanım elde edildiğini vurgulayarak şu noktalara dikkat çekmiştir:

"Bunu yapmakla gericilik mücadelesinin ilk kazmasını vurmuş oluyoruz. Türk çocuğunun yetişmesi için bütün cepheleriyle birçok eğitime ihtiyacı vardır. Bunun için Türk çocuğu öğretmenin eline teslim edilmiştir. Çocuklarımızı bütünü ile yetiştirecek Türk öğretmenine, şu çizdiğimiz ana hatlar dahilinde pedagoji metotlarına uygun bir şekilde çizilen bir çerçeve içinde faydalı ve mutlak zararsız bir ölçü ile ve vatandaşı da tatmin ederek ve hiçbir zaman memlekete zarar vermeyerek din terbiyesini de verdiriyoruz." (Beşinci Milli Eğitim Şûras1, 1954: 381)

İleri konuşmasında şu hususlara da yer vermiştir:

"Biz vatandaşla karşı karşıyayız. Bu mevzuda vatandaşı tatmin ile mükellefiz. Vatandaş çocuğuna bizim mekteplerimizde, bizim laik memleketlerimizde sizin mübarek ve nurlu ellerinizle dini bilgilerin verildiğini anladiğ anda para vererek, misır vererek, buğday vererek çocuğunu cahil hocaya teslim etmez. O halde bunun üzerinde dikkatli durmamı lazımdır. Bu bilgileri en halis şekilde çocuklarımıza verdiğimize bütün vatandaşları inandırmamız lazımdır." (Beşinci Milli Eğitim Şûras1, 1954: 382)

Genel kurulda bu konuyla ilgili uzun tartışmalar yapılmış olmakla birlikte, Esen ve İleri'nin yukarıda alıntılanan konuşmaları tartışmanın özünü teşkil etmiş; diğer konuşmalar daha çok bu temel konuşmaları destekler veya eleştirir nitelikte, aynı tezler üzerinden ilermiştir. Bu tartışma, Beşinci Milli Eğitim Şûrası'na damgasını vuran en önemli tartışmadır.

\subsection{Altıncı Milli Eğitim Şûrası (18 - 23 Mart 1957)}

DP iktidarı döneminin ikinci milli eğitim Şûrası olan Altıncı Milli Eğitim Şûrası 18 - 23 Mart 1957 tarihleri arasında Ankara İsmet Paşa Kız Enstitüsü'nde yapıldı. Bu şûra, DP'nin kurduğu dördüncü hükümet dönemine denk geliyordu. 550 (Altıncı Maarif Şûrası, 1957: XIX - XXXVI) delegenin katılımıyla gerçekleşen şûranın başkanlığını dönemin Millî Eğitim Bakanı Ahmet Özel yaptı. 
Özel, şûranın açış konuşmasında, şûranın gündeminde bulunan konulara kısaca değindi. Mesleki ve teknik eğitim konusu, mesleki ve teknik eğitimin önemli bir dalını teşkil ticaret eğitimi ve halk eğitimi Özel'in konuşmasında değindiği temel konulardı (Altıncı Maarif Şûrası, 1957: 7 - 30). Özel konuşmasında mesleki ve teknik eğitimle ilgili olarak şu ifadelere yer verdi:

"Mesleki ve teknik öğretimin dünya yüzündeki ehemmiyetine sayın şûra üyeleri her cephesi ile vakifturlar; bu konunun, asrin yeni vasita ve metotlarindan faydalanan memleketimizin ekonomik ve endüstriyel hayatıyla ne kadar sıkı bir şekilde alakalı olduğunu da takdir etmektedirler. Milletimizin bugünü ve yarını bakımından bu derece ehemmiyetli bir faaliyet şubesinde gerekli tekamülü temin etmek vazifemizdir." (Altıncı Maarif Şûras1, 1957: 5 - 6)

Mesleki ve teknik eğitim kapsamında ticaret öğretiminin önemine özellikle dikkat çeken Özel'in bu konuyla ilgili saptamaları şöyleydi:

Ticari iş bilgilerinin genel eğitimimiz içerisinde daha ehemmiyetli bir yer almasını, memleketimizin ihtiyaçları bakımından zaruri görmekteyiz. Şüphe yoktur ki bu eğitim ve ögretim nazari kalmamal, hayatımızın yeni inkişaflarına uygun, reel bir eğitim ve ögretim olmall, öğrencileri manen teşebbüs ruhu ile, maddeten de üstün bir teknikle teçhiz etmelidir." (Altınc1 Maarif Şûras1, 1957: 22)

Özel halk eğitimine ilişkin görüşlerini de şöyle açıkladı:

“... yetişkinlerin eğitimi, fikri ve manevi tekamülleri de öğrenim çă̆ında bulunanlarınki kadar mühimdir. Bu sahada memleketimizin Millet Mektepleri yoluyla geçirmiş olduğu tecrübe hatıralardadır. $O$ günden bugüne kadar halk eğitimi istediğimiz vüs'atte olmamakla beraber, ümmilikle mücadele bakımından köy okullarında, mesleki bakımdan da teknik ögretim okullarında devam edegelmiştir. ... Bu eğitimin, ümmilikle mücadeleden başka, iyi yaşama, vatandaşlık ve sağllk bilgileri verme, halkı aydinlatma, mesleklere hazırlama, verimi artırma ve umumiyetle mesleklerde ilerlemeyi sağlama gibi hedefleri olması da tabiidir. Esasen eğitimin gayesi, ferdi sosyal hayata hazırlamak, seviyeli, moral hayata kavuşturmaktır. Bu da onu bir meslek sahibi knlmak suretiyle tahakkuk safhasına girer. Memleketimizde ümmilik nispeti, nesiller arasındaki bazı görüs farklarl, birçok sahalarda makineli istihsal devrine girmiş olmamız, bir meslek sahibi olmak veya türlü mesleklerde ilerlemek isteyen vatandaşların çokluğu göz önüne getirilince bu alandaki işlerimizin de ne derece mühim ve müstacel olduğu anlaşılır." (Altınc1 Maarif Şûras1, 1957: 6)

Şûranın gündeminde bulunan temel konularsa şöyleydi:

1. Mesleki ve Teknik Öğretim 

a. Erkek Teknik Öğretim
b. Kız Teknik Öğretim
c. Ticaret Öğretimi

2. Halk Eğitimi (Altıncı Maarif Şûrası, 1957: XI - XII)

Şûra, bu gündem maddelerini 4 farklı komisyonda ele aldı (Altıncı Maarif Şûrası, 1957: XII). Komisyonlar, konuları tartışıp, raporlarını hazırladı. Ardından komisyonlardan gelen raporlar genel kurulda görüşülüp karara bağlandı.

$\mathrm{Bu}$ şûranın da aynı daha önceki şûralar gibi uygulama alanı bulan kararları olduğu gibi, uygulama alanı bulmayan kararları da olmuştur. Şûra, Türkiye'nin içinde bulunduğu sosyal ve ekonomik mevcut ve potansiyel sorunlara, mesleki ve teknik eğitimi odağına alarak öneriler geliştirmeye çalışmıştır. Yine halk eğitimi de bu kapsamda şûranın odağında bulunmuştur. Şûranın Türkiye eğitimine en önemli katkısı da halk eğitimi konusunu ilk kez bir Şûra gündemine getirmesi ve bu konuyu bilimsel olarak ele almasıyla ilgili olmuştur (Dinç, 2015: 180). Genel kurulda komisyon raporlarının görüşülmesi sırasında, önceki milli eğitim Şûralarında karşılaşın ciddi görüş ayrılıkları ve tartışmalar yaşanmamıştır.

\section{Sonuç}

Bu çalışmada DP döneminde toplanan Milli Eğitim Şûraları ele alındı. 14 Mayıs 1950 seçimleriyle iktidara gelen ve Türk Silahlı Kuvvetlerinin yönetime el koyduğu 27 Mayıs 1960 tarihine kadar iktidarda kalan DP döneminde, iki milli eğitim şûrası toplanmıştı. Bunların ilki 4 - 14 Şubat 1953 tarihleri arasında çalışan Beşinci Milli Eğitim Şûrası, ikincisi de 18 - 23 Mart 1957 tarihleri arasında çalışan Altıncı Milli Eğitim Şûrası'ydı. Çalışmada önce, DP iktidarı dönemine kadar olan süreçte toplanan milli eğitim şûraları ana hatlarıyla özetlendi; bu özet, milli eğitim şûraları öncesinde yapılan benzer toplantıların mirası da dikkate alınarak genişletildi. Birinci Maarif Kongresi, birinci, ikinci ve üçüncü heyet-i ilmiye toplantıları ile ilk dört milli eğitim şûrası özete konu edilen söz konusu toplantılar arasındaydı. Bu özetin ardından genel hatlarıyla DP iktidarı döneminin siyasal özellikleri, temel evreler altında gösterildi. Sonrasındaysa DP döneminde toplanan iki milli eğitim şûrasının incelemesine geçildi. Çalışmada bu şûraların gündemleri, uygulama alanı bulan veya bulamayan önemli kararları anlatıldı. Ayrıca şûralarda yaşanan önemli tartışmalara da genel hatlarıyla yer verildi.

DP döneminin ilk milli eğitim şurası olan Beşinci Milli Eğitim Şurası, ağırlıklı bir biçimde ilkokul eğitimini konu etmiştir. İlköğretim Kanunu tasarısının ve yeni İlkokul Yönetmeliği tasarısının incelenmesi, ilkokul programının gözden geçirilmesi, zorunlu ilköğrenimin planlanması, ilkokullarda sağlık konusu ile ilgili alınması gereken önlemlerin saptanması ve ilkokullara öğretmen yetiştirilmesi şuranın ilgilendiği temel konulardan olmuştur. Şura bunların yanı sıra okul öncesi eğitim ve anaokullarını, özel eğitime muhtaç çocukların eğitimiyle ilgili hususları da ele almıştır. Beşinci Milli Eğitim Şurası'nın gündem ekseninde özgün boyutu, okul öncesi eğitim konusunu ele 
alarak tartışması olmuştur. DP döneminin ikinci milli eğitim şurası olan Altıncı Milli Eğitim Şurası'ysa iki temel konu üzerine durmuştur. Bunlardan birincisi mesleki ve teknik eğitimdir. Şura bu konuyu erkek teknik eğitim, kız teknik eğitim ve ticaret öğretimi alt başlıkları altında ele almıştır. Şuranın üzerinde durduğu ikinci temel konuysa halk eğitimi olmuştur. Daha önceki şuraların gündeminde bulunmayan halk eğitimi konusu, ilk kez bu şurayla gündem maddesi yapılmıştır. Bu, Altıncı Milli Eğitim şurasının gündem eksenindeki boyutunu teşkil etmektedir. Beşinci Milli Eğitim Şurası okullarda din eğitimi konusu kapsamında hararetli tartışmalara sahne olurken, Altıncı Milli Eğitim Şurası'nda genel kurulu meşgul eden ciddi bir tartışma yaşanmamıştır.

Yeni Türkiye yapılandırılırken, yetişecek Cumhuriyet kuşakları, Cumhuriyet'in ve onun ideolojisinin temel garantisi olarak görüldü. Bu çerçeve içinde eğitime, yeni Cumhuriyet kuşaklarının, Cumhuriyet ideolojisine uygun biçimde yetiştirilmesi yönünde kritik bir misyon yüklendi. Erken Cumhuriyet döneminde siyasal iktidar, eğitim politikalarını, eğitime yüklediği bu misyonla uyumlu biçimde geliştirdi. Bu noktada eğitim sistemini şekillendiren temel talep daima siyasal iktidardan geldi. Eğitimin ihtiyaçları, aslında siyasal iktidarın ihtiyaçlarıydı ve bu ihtiyaç da daha çok Cumhuriyete sahip çıkacak yurttaşların yetiştirilmesiyle ilgiliydi; bir diğer deyişle ideolojikti. Öte yandan yeni Türkiye, iktisadi ve sosyal kalkınma anlamındaki hedeflerini gerçekleştirmek için de yüzünü eğitime döndü. Nitelikli işgücünün yetiştirilmesi bu anlamda eğitime yüklenen misyonun en yalın ifadesi oluyordu. Nitelikli işgücü kapsamında eğitim sistemine yönelen talebin kaynağı yine büyük ölçüde siyasal iktidar olmakla birlikte, bu noktada talep üreten bir özne olarak, Türkiye'deki iktisadi gelişmelere bağl1, iş çevreleri ve sermaye de yavaş yavaş devreye girmeye başladı.

Milli eğitim şuraları öncesi dönemdeki benzeri toplantılar ve DP dönemi öncesinin milli eğitim şuraları, eğitim sistemine yönelen bu iki temel talebin çok çeşitli yönleriyle masaya yatırıldığı, bilimsel anlamda formüle edildiği toplantılar oldu. Bu talepleri yanıtlayabilmesi için eğitim sisteminin nasıl şekillendirilmesi gerektiğine dair çözümlerse bu toplantıların en önemli boyutu oldu. DP döneminde toplanan iki milli eğitim şurası, bu anlamda bir kopuşu değil, bir sürekliliği simgeliyordu. Ancak DP döneminin iki şurası kendilerini, kendilerinden önceki şuralardan ve benzeri diğer toplantılardan ayıran bir özelliğ de bünyesinde barındırıyordu. Bu, eğitim sisteminin şekillenmesine ilişkin, sisteme ulaşan taleplerin kaynağıyla ilgiliydi. Şurada siyasal iktidarın ve iş/sermaye çevrelerinin yanı sıra halkın talebi de gündeme alınıyor, bu talep de daha çok din eğitimi kapsamında şekilleniyordu. Halkın talebinin, bir gündem tartışması olarak şuraya girmesiyse, kuşkusuz ki değişen siyasal yapıyla, siyasal yapının rekabetçi hale dönüşmesiyle ilgiliydi. $\mathrm{Bu}$ talebin karşılanması bir anlamda seçmenin ihtiyacının karşılanması anlamını taşıyacak ve seçmenlerin siyasal parti tercihinde belirleyici olabilecekti. 


\section{Kaynaklar}

Akgül, H. (2006), IV. Milli Eğitim Şûrası (22 - 31 Ağustos 1949), Bilgi ve Bellek, S. $6,175-187$.

Akyüz, Y. (1985), Türk Ĕgitim Tarihi, Ankara: Ankara Üniversitesi Eğitim Bilimleri Fakültesi Yayınları.

Altıncı Maarif Şûrası (Çalışma Esasları, Komisyon Raporları, Konuşmalar), (1957), T.C. Maarif Vekâleti Yayınları.

Atatürk’ün Söylev ve Demeçleri, (1997), C. 2, Ankara: Atatürk Kültür, Dil ve Tarih Yüksek Kurumu Atatürk Araştırma Merkezi Yayınları.

Beşinci Milli Eğitim Şûrası (Çalışma Esaslart, Komisyon Raporlart, Konuşmalar), (1954), T.C. Maarif Vekâleti Yayınları.

Birinci Maarif Şûrası (Çalışma Programı, Konuşmalar, Lahikalar), (1939), Ankara: T.C. Maarif Vekilliği Yayınları.

Dinç, S. (2015), Türk Eğitim Tarihinde Yapılan Milli Eğitim Şûraları ve Uygulamaları (1939 - 1960), Ankara: Akademisyen Kitabevi.

Dördüncü Milli Eğitim Şûrası (Çalışma Programı, Komisyon Raporları, Konuşmalar), (1949), Ankara: T.C. Milli Eğitim Bakanlığı Yayınları.

Eroğul, C. (1998), Demokrat Parti: Tarihi ve İdeolojisi, Ankara: İmge Kitabevi. İkinci Maarif Şûrası (Çalışma Programı, Raporlar, Konuşmalar), (1943), Ankara: T.C. Maarif Vekilliği Yayınları.

Istatistik Göstergeler (1923 - 1995), (1996), Ankara: Devlet İstatistik Enstitüsü Yayınlar1.

Sakaoğlu, N. (2003), Osmanlı'dan Günümüze Eğitim Tarihi, İstanbul: İstanbul Bilgi Üniversitesi Yayınları.

Tekeli, Ş. (1996), Cumhuriyet Döneminde Seçimler, Cumhuriyet Dönemi Türkiye Ansiklopedisi, C. 7, 1798 - 1824.

Tunaya, T. Z. (1952), Türkiye'de Siyasal Partiler (1859 - 1952), İstanbul: Arba Yayınlar1.

Üçüncü Milli Eğitim Şûrası (Çalışma Programı, Komisyon Raporları, Konuşmalar), (1947), Ankara: T.C. Milli Eğitim Bakanlığı Yayınları.

Yücel, H. Â. (1994), Türkiye'de Orta Öğretim, Ankara: T.C. Kültür Bakanlığı Yayınları.

Zelyut, R. (1996), Milli Eğitim Şûraları, Cumhuriyet Dönemi Türkiye Ansiklopedisi, C. 3, $642-680$. 